\title{
Supportive Organizational Culture and Employee Job Satisfaction: A Critical Source of Competitive Advantage. A Case Study in a Selected Banking Company in Oxford, a City in the United Kingdom
}

\section{Elvis Asiedu*}

National Learning Service (SENA), Neiva, Huila, Colombia, South America

\begin{abstract}
Banking jobs are becoming more and more lucrative and many people are joining the industry. Although numerous scholars have written more about the topic, many have failed to research into the banking industry on how organisational culture and employee job satisfaction can be used as a source of competitive advantage.

This study investigates on how the impact of organisational culture on employee job satisfaction can be a source of competitive advantage. Using a case study method, the paper derives quantitative data from the employees of a selected banking company in Oxford, a city in United Kingdom. The selected banking company has four (4) branches in Oxford and it is the worst banking institution with few customers. The company has 100 workers working in all the four branches across Oxford city.

A review of literature in two-fold: (i). Understanding supportive organisational culture and employee job satisfaction and (ii). The impacts of organisational culture on the employee job satisfaction as a source of competitive advantage are conducted. This is followed by a summary of methodology and data analysis, ethical consideration and conceptual framework. Empirical analysis was conducted to determine the effects of organisational culture on employee job satisfaction as a source of competitive advantage. The empirical findings show that cultural traits of communication, motivation, growth opportunities and supervising support in organisations tend to make employees shift mind set and help the firm in its competitive advantage. However, the discussion found out that employees within the company were not motivated enough to perform better due to lack of rewarding culture, growth opportunities (training) culture, communication and supervisory supportive culture.
\end{abstract}

Keywords: Organisational culture; Job satisfaction; Communication; Motivation; Supervisory support and growth opportunity

Abbreviations: OCEJS: Organisational Culture and Employee Job Satisfaction; OC: Organisational Culture

\section{Introduction}

In recent years, employee job satisfaction has become widely accepted as one of the most important management disciplines [1]. This is because most organisations want to retain their employees and raises their performance level to achieve a competitive advantage.

The supportive culture traits of motivation, communication, growth opportunities and supervisory support make employee feel empowered to think and behave as a leader within their domain. The combination of physiological, psychological and environmental circumstances that causes an employee to voice out and say "I am satisfied with my job" is what Hoppock [2] referred to as Job Satisfaction. It is argued that supportive culture in every organisation results to employee job commitment which in turn influences employee performance. Job satisfaction is something that makes a worker or an employee feel that he/she is fully part of the organisation and happy to give all his/ her best to improve the performance level of the company. Employees working hard and giving all their best position the company above its competitors.

Researchers like Jiang and Klen, Mckinnon, Taber, Waliser, Rad, Chang and Lee, Arnold [3-7] link employee job satisfaction with many organisational culture factors such as the culture of rewarding, participation in decision making, growth opportunities, supervising support, and compensation. This is because an organisation with a supportive culture; its employees also really understand what is required of them and they try to work in accordance with the core values to achieve aims of that company. Organisational culture is one which is embedded deeply into the ways a business does things and the ability to come out with new ideas of doing things and getting things done in the company. A company however, can fail to gain employee job loyalty and satisfaction when there is weak organisational culture.

A weak organisational culture refers to the organisational culture which is not embedded deeply into the ways an organisation does things. With a weak organisational culture, there is lack of focus, poor motivation and poor communication as a result of clearly undefined core values and norms within the organisation. Employees in such organisations are always lost as far as the core values of the company are concerned and do not know and understand what is required of them. Riley [8] argues that weak organisational culture sometimes occurs if there is little alignment between the espoused values and the way things are done within the organisation. He continues that this can lead to inconsistent behaviour and dissatisfaction of employee job satisfaction within the organisation which in turn results to inconsistent customer experiences.

Oxford is a city and county town of Oxfordshire in Central Southern England, UK with a population of over 150200. Oxford forms a district within the county and lies within the Oxford Metropolitan area with

*Corresponding author: Elvis Asiedu, Lecturer, National Learning Service (SENA), Neiva, Huila, Colombia, South America, Tel: +57 310279 0179; E-mail: elvisasiedu63@yahoo.com

Received May 28, 2015; Accepted June 26, 2015; Published June 31, 2015

Citation: Asiedu E (2015) Supportive Organizational Culture and Employee Job Satisfaction: A Critical Source of Competitive Advantage. A Case Study in a Selected Banking Company in Oxford, a City in the United Kingdom Int J Econ Manag Sci 4: 272. doi:10.4172/21626359.1000272

Copyright: ( 2015 Asiedu E. This is an open-access article distributed under the terms of the Creative Commons Attribution License, which permits unrestricted use, distribution, and reproduction in any medium, provided the original author and source are credited. 
a total population of 244000 . The city of Oxford is one of the fastest growing cities in UK in terms of population.

The researcher, having spent a substantial part of his life in Oxford, has worked as a banker and witnessed dissatisfaction of most employees in the selected banking company. He approached the management and asked to use their banking institution to conduct research on the impacts of organisational culture on employee job satisfaction: a critical source of competitive advantage. Both the researcher and the management saw this study vital because the selected company was in the middle of losing its experienced employees and loyal customers without any tangible excuse. In view of that, a request showing interest in having their organisational culture and employee job satisfaction diagnosed was made and accepted by the area manager.

This paper seeks to determine the impacts of organisational culture on employee job satisfaction as a source of competitive advantage within organisations. The aim is to understand the various responses of workers in this industry about organisational culture and employee job satisfaction. The paper also scrutinises the impact of culture on employee job satisfaction as a competitive advantage. The contributing findings and discussions also offer validity of the hypothesis surrounding the critical importance of employee satisfaction and loyalty.

\section{Purpose of study}

The purpose of the research is to investigate on how the impacts of organisational culture on employee job satisfaction can be a critical source of competitive advantage.

\section{Research objectives}

In order to achieve the above purpose of the research, the following objectives were set aside to deal with;

- To explore the various culture factors that ensures the success of employee job satisfaction in organisations.

- To verify the importance of organisational culture of the selected bank on their employee Job Satisfaction in organisations: a critical source of competitive advantage.

- To suggest recommendations on how the selected company can restructure its organisational culture to empower employees.

\section{Research questions}

- Do organizations with high adhocracy of culture traits such as motivation, growth opportunity, communication and supervision ensure employee job satisfaction?

- Does your organisational culture have a significant impact on the employee job satisfaction?

\section{Literature Review}

\section{Understanding supportive organisational culture and job satisfaction}

Every organisation in this world has a culture, whether it is deliberately implemented or not. However, some appears to be more supportive than others and that is what this study seeks to answer. Scholars like Kathryn, Perrow, March and Simon [8-11] among others initially conceptualized supportive organisational culture as a coherent set of values, beliefs, assumptions and practices among the employees within the organisation. These scholars further explained by putting much emphasis on the pervasiveness of consistent values, beliefs, assumptions and practices as well as the extent of consistency of the various values, beliefs, assumptions and practices of its members within the organisation. Other proponents also argue that a supportive and pervasive organisational culture tend to benefit the organisation since it fosters commitment, motivation, solidarity, identity and sameness which turn to facilitate employee job satisfaction.

Organisational Culture is based on cognitive systems which help to explain how employees think about and make decision. Charles and Gareth argued that, "organisational culture is the specific collection of values and norms that are shared by people and groups in an organization. To them, the culture of the organisation control the way employees interact with each other and with stakeholders outside the organisation." In the words of Schneider [12], organisational culture is the value of systems and assumption which guide the way the organisation runs its business. This shows that the organisation's norms and values have a strong effect on all those who are attached with the organisation. He further explained that, the norms are invisible but if the organisation want to improve upon the performance of the employees and profitability, then norms must be their first priority.

Contrary to the above assessment, Perrow [10] observe that supportive culture could sometimes result to employee unconstrained demanding from the company which can negatively be used as a barrier to adaptation and change by employees. March and Simon [11] further explain that supportive culture like rewarding and compensation, growth opportunities (training), communication and supervisory support can sometimes lead to displacement of goals. They argue that these supportive cultures can shift employee's attention from the organisational goals to their personal development and gains. Merton [13] added that if the behavioural norms and ways of doing things become more important, it can overshadow the original purpose of the organisation.

Despite the above contradictory assessment, Schein [14] still believe that supportive culture like rewarding and compensation, communication, training and growth opportunities as well as supervisory support are conservative force for employee job satisfaction and a source of competitive advantage for a firm. He however, argues that the culture of every modern organisation should be supportive but limited to certain conditions.

Job satisfaction according to Pennington and Riley [8] is an external and internal value in which an employees' general assessment of how satisfied he/she is on the job is based on the strong culture of such organisation. This means that a strong culture of every business enhances employee self-confidence and reduces job stress. Saffold argues that consistent training of employees ensures commitment and improves ethical behaviour of the people working in an organisation. It is strongly argued that a weak organisational culture can arise when the core value of an organisation are not clearly defined, communicated or widely accepted by those working for the company [8]. It sometimes occur when there is little alignment between the way things are done and the espoused values. This normally leads to inconsistent behaviour of the employees which in turn results in inconsistent customer experience.

Gutknecht and Miller [15] on the other hand explain organisational culture as the representative of the organisation's soul, purpose and foundation. This describes that the organisation and the people influence one another positively to achieve better results [16]. These two scholars further argue that employees in the organisation are the role models and because of them organisations become more successful. Desatnic et 
al. observed the various explanations above and drew a conclusion that organisational culture is the personality of the organisation.

In trying to explain employee satisfaction, Lock [17] argued that it is the positive emotional or pleasurable state resulting from the appraisal of one's job or job experience. According to Schneider et al. [12], job satisfaction on the side of employee is a personal evaluation of conditions that are present in the job. It fully involves the outcomes that arise when someone secures a job. This indicates that employee job satisfaction involves individual's perceptions and evaluation of his job. They argued further that, this perception is influenced by the person's unique circumstances like values, needs and expectation. To amass everything, Kerego and Muthupha [16] joined hands with the above scholars and concluded that employee job satisfaction is the feelings of workers about the environment they work.

\section{Organisational culture and employee job satisfaction as a critical source of competitive advantage}

It is argued that hiring of the best people for your firm doesn't guarantee the success of the firm. However, hiring and developing competent employees through effective culture values such as communication, motivation, growth opportunities and supervisory support can guarantee and grant the firm a competitive advantage over its competitors.

Developing in this context of study involves adopting culture traits above to determine and guide the employee behaviour. When employees are satisfied with the culture of the organisation, it makes them feel complete and sell the company to outsiders. Rad [5] argued that employee job satisfaction is determined and affected by the culture of the organisation. He continued that satisfied employee can guarantee the success of the organisation by working wholeheartedly and selfless to grant the company a competitive advantage over its competitors. Scholars such as Reilly and Robbert, Kram, Gorries [18,19] among others believe that the various forms of communication in the organisation as well as the relationship between the employer and the employee (worker) have positive impact on the way employee go about their daily routines at the workplace.

Another Organisational Culture (OC) assessment model on employee job satisfaction as a critical source of competitive advantage developed by Kline and Boyd (1994) determine the relationship between the structure of the organisation and the job satisfaction. These two scholars observed that employees at various levels of work are influenced by different work aspects and diverse facets of work environment. Muthupha and Kerego [16] continued that the conditions of working and channels of communication highly affect the job satisfaction of employee and sends excellent signal to customers outside. The way employees are addressed at workplace by their superior can have a positive impact on the company's competitive advantage. Aggrieved and dissatisfied employee will not have time to explain products and services to a customer. Losing a single customer a day can cost the firm to loose seven customers within a week.

Wallack suggest that employee job satisfaction and job performance are related to the culture of the organisation. To him, job satisfaction and culture are interdependent on each other and both have a strong effect on the organisation's competitive advantage. It is based on this that made Kraower and Zammuto to argue that management of the organisation with the positive culture can enhance the job performance, loyalty and satisfaction of the employees. In the words of Sampene et al. [20], there is a close relationship between organisational culture and job satisfaction. They explain that strong organisational can yield employee job satisfaction. On the contrary according to them, some facets prove negative relations and other positive relations. Their explanation is that the varied relations depend on the employees perceive cultural values and uniqueness. It should be noted that not all organisational culture can build competitiveness unless it meets employee and customer values.

According to Hansen et al., the attitude and behaviour of the employees towards their job whether intentionally or unintentionally is strongly determined by the culture of the organisation. Huang and Chi [21] argue that if the employees are well satisfied with the organisation's culture, they will be motivated to work diligently to improve the performance level of the company over its competitors. To them, the employee's obligations will be consistent which would finally raise the performance level of the organisation. Jiang and Klein [3] reveal in their study that, the supportive culture of every organisation can increase employee job satisfaction and decrease the turnover ratio of the organisation.

In addition to the above assessments, McHugh et al. develop that weak culture result to lower level of job satisfaction and lower productivity from the employees. He continued that, weak culture can decrease the performance and efficiency level of the organisation. The organisation with suitable and strong culture affects positively only not employee satisfaction but also improves job commitment of the workers within the organisation which in turn grants the firm a competitive advantage. To crown everything, McKinon, Mansoor and Tayib, Yousaf, Arnold [22,23] conclude that, organisation's with strong culture brings positive impact on employee job loyalty and satisfaction.

Although all organisations have culture but any organisation that fails to implement culture traits of rewarding and compensation, communication, growth opportunities and training and supervisory support fail to engage their employees. The consequences of disengaged employees can have detrimental effects on the organisation's competitive advantage. This is because dissatisfied employees would never give out their best to see the company moving ahead of its competitors (Corporate Leadership Council, 2004). Clugston [24] argues that, organisational culture with employee satisfaction can influence the employee commitment deliver its services to climb to the top.

\section{Research Methodology and Data Analysis}

Research aims decides what needs to be achieved with the conduct of a study and therefore keeping in view the objectives to be achieved; the researcher evaluates which approach suits best to the attainment of purpose [25]. To realise the objectives of this research and test the research questions, the researcher adopted the two levels of research strategy, thus, primary and secondary research.

In using the secondary sources, the researcher consulted variety of subject disciplines of organisational behaviour with regards to culture and employee satisfaction. Besides, national and international data searches at Oxford City-Centre Library, BPP Library-London, Oxford University Library and relevant abstracts and indexes were consulted. Other secondary data that were found to be relevant to this research included (Table 1).

The researcher in an attempt to make sure the information provided was authentic, reliable and valid, primary sources which focus on survey research strategy was conducted. The employees of the selected banking company in Oxford constituted the target population for the study. The 
employees were selected from all the four (4) branches (Hayford Hill, Cowley Road, City Centre and Westgate branches) respectively.

The selected bank have 100 employees across all the four branches and this is the breakdown; Hayford Hill (35 employees), Cowley Road, (25 employees), City Centre (20 employees) and Westgate (20 employees). In collecting the data for the research, the researcher used structured questionnaires as the research instruments. The questions were both close ended and open ended and were designed to elicit respondents' views on aspects of the research study to ascertain the need and importance of organisational culture on employee job satisfaction. For the open-ended questions, the researcher asked the questions and allowed the respondents (employees) to give their answers. See appendix for the open-ended questions.

The questionnaires have Five (5) Likert Scale ranging from "strongly agree" to "strongly disagree". The questionnaires were based on demographic variables and items related to job satisfaction and organisational culture. The first four (4) questions on organisational culture were adapted from Yang and the other six (6) questions on employee job satisfaction were taken from Specter respectively. The questions were chosen based on the framework of the study and were in two-fold, namely:

(1) The first four survey questions in Table 2 answers Research Question (RQ) No.1 to find out the respondents general idea on supportive organisational culture on employee job satisfaction as discussed in the literature review, (2) The second six survey questions in Table 2 answers RQ No.2 to find out whether the organisational culture in their company has a significant impact on the employee job satisfaction.

The sampling procedure adopted for the study was random sampling since employee job satisfaction is a potential human characteristic. That is, data was collected through personal contacts and questionnaires from employees found at the selected banking company who worked in all the Four branches in Oxford. According to McQuitty, sampling size of this kind of research is considered to be critical in achieving sufficient statistical power. Contrary to that, Schreiber et al. argue that the normality of the data and estimation methods require a minimum sample size. Scholars like Nunnally and Schreiber et al. opine that there is a general rule of ten observations for every free parameter (Figure 1).

The researcher distributed 70 questionnaires among randomly selected workers at the selected banking company in Oxford. This was done to exceed the minimum requirement of the sample size. Out of the 70 questions, 50 were returned with the response rate of $71.4 \%$. To test the validity and reliability of the data, there was pre-test on a few individuals to see that the questionnaires were reliable. Besides, there was also test re-test method to determine the reliability of the information to discount any inconsistency of information provided by the respondents.

\section{Ethical considerations}

Remenyi suggest that researchers need to have a firm understanding of what is considered wrong and right when researching. He continued that researchers are in a privileged position where they gain information from respondents. And as matter of fact, they are expected to perform their duties and use the information gained in an ethical manner. Remenyi has grouped how research should be conducted ethically into three manners and the Table 3 below explains them in details.

\section{Conceptual framework for competitive advantage}

In an attempt to address whether organisational culture has significant impact on employee satisfaction, the researcher proposed a framework called Elvis OCEJS (Organisational Culture and Employee Job Satisfaction) model.

The framework proposes that organisations with high adhocracy of culture traits such as motivation culture (fair rewarding, compensation, job security, fairness in appraisal and promotions, fairness of pay and benefits), growth opportunity culture (employee training, education, career development opportunities), communication culture (exchange of ideas, facts, emotions, and respect) and supervision support culture (support with personal and family matters, fairness in personnel procedure) lead to higher levels of employee job satisfaction and job satisfaction of employees positions a firm above its competitors.

The researcher believes that a company can become a company of choice depending on employees preference for working and commitment. He argued that conducting a marketing research on customers to attain competitive advantage will be waste of time if the employees are not satisfied. He continued that the company can channel such resources to find out what really bothers, motivates and challenges its employees. This is important because a satisfied employee will be pleased to receive customers in a good mood. Below is Elvis OCEJS framework:

The framework suggests that effective management empower their employees, build their organisations around them and develop human capability at all levels. The researcher in trying to justify his framework explained that, employees become committed to their company when they feel that they own a piece of the organisation and that is where supervising support and motivation traits comes in. Looking at the competitiveness of the marketplace, winning is not only about

\begin{tabular}{|c|c|c|}
\hline $\begin{array}{l}\text { Research articles, books, } \\
\text { and journals with focus on } \\
\text { organisation commitment } \\
\text { of employees such as } \\
\text { Greenberg, Meyer and } \\
\text { Allen, Ahmed Shah, } \\
\text { Detert and Schronedar } \\
\text { and Allen and Meyer }\end{array}$ & $\begin{array}{l}\text { Research journals, books, } \\
\text { articles dealing with the } \\
\text { organisational culture } \\
\text { within a selected } \\
\text { organisation like Rowe } \\
\text { et al., Herriengel et } \\
\text { al., Clugston et al. and } \\
\text { Husted }\end{array}$ & $\begin{array}{l}\text { Also books and } \\
\text { government publications } \\
\text { on employee job } \\
\text { satisfaction such as } \\
\text { Weber and Camerer and } \\
\text { Wang X }\end{array}$ \\
\hline
\end{tabular}

Table 1: Secondary data found to be relevant to the research.

\begin{tabular}{|c|c|c|}
\hline $\begin{array}{l}\text { Respondents' } \\
\text { demographics }\end{array}$ & $\begin{array}{l}\text { Frequency (No. of } \\
\text { Respondents) }\end{array}$ & Percentage \% \\
\hline $\begin{array}{rr}\text { Gender }(\mathrm{N}=50) & \text { Male } \\
\text { Female }\end{array}$ & $\begin{array}{l}30 \\
20\end{array}$ & $\begin{array}{l}60 \\
40\end{array}$ \\
\hline $\begin{array}{rr}\text { Age }(\mathrm{N}=50) & 18-25 \\
& 25-35 \\
& 35-40 \\
& 40-50 \\
& \\
& \end{array}$ & $\begin{array}{l}12 \\
15 \\
13 \\
6 \\
4\end{array}$ & $\begin{array}{c}24 \\
30 \\
26 \\
12 \\
8\end{array}$ \\
\hline $\begin{array}{c}\text { Qualifications }(\mathrm{N}=50) \\
\text { Degree/above } \\
\text { College } \\
\text { High School } \\
\text { Other }\end{array}$ & $\begin{array}{c}7 \\
13 \\
15 \\
15\end{array}$ & $\begin{array}{l}14 \\
26 \\
30 \\
30\end{array}$ \\
\hline $\begin{array}{c}4 \text { Branches }(\mathrm{N}=50) \\
\text { Hayford Hill } \\
\text { Cowley Road } \\
\text { Westgate } \\
\text { City Centre }\end{array}$ & $\begin{array}{c}20 \\
15 \\
7 \\
8\end{array}$ & $\begin{array}{l}40 \\
30 \\
14 \\
16\end{array}$ \\
\hline
\end{tabular}

Table 2: Presents the demographic details of the respondents. 


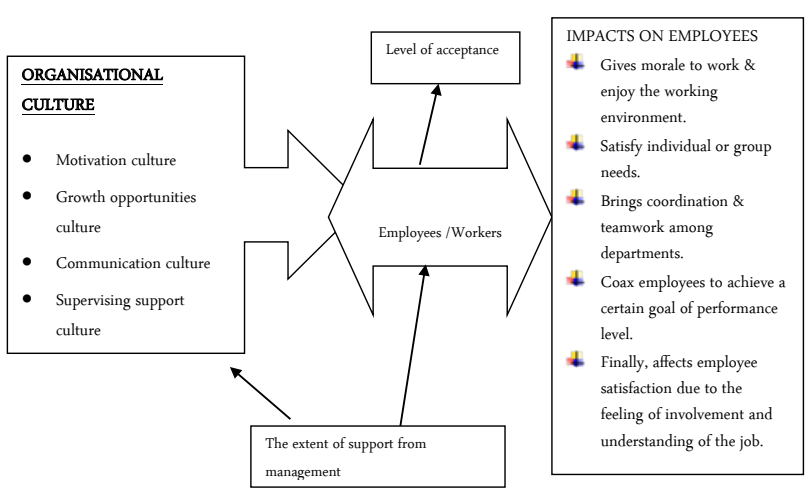

Figure 1: Organisational culture and its impact on employees. Source: OCJS framework for employee job satisfaction.

\begin{tabular}{|l|l|}
\hline $\begin{array}{l}\text { Issues regarding data } \\
\text { collection: }\end{array}$ & $\begin{array}{l}\text { With this, the researcher ensured that there } \\
\text { was non-disclosure of the respondents' details and } \\
\text { no authentication was attached to the submitted } \\
\text { questionnaires. The researcher explained to the } \\
\text { employees involved in the survey the importance of } \\
\text { the research (Remenyi, 1998, 110). }\end{array}$ \\
\hline $\begin{array}{l}\text { Problems associated with } \\
\text { processing the data: }\end{array}$ & $\begin{array}{l}\text { attempt to omit or manipulate to distort the data } \\
\text { (Remenyi, 1998). The researcher acted in an } \\
\text { unbiased manner, with no personal prejudices } \\
\text { influencing the collection and analysis of data } \\
\text { (Remenyi, 1998; 111). }\end{array}$ \\
\hline The use of findings: & $\begin{array}{l}\text { According to Remenyi (1998; 112), the findings } \\
\text { of the research should be used for ethical purposes } \\
\text { only. In view of this, the researcher used the findings } \\
\text { for academic purposes. }\end{array}$ \\
\hline
\end{tabular}

Table 3: Ways research to be conducted ethically into three manners.

having money, strategy and technology, but it's about redesigning the culture of the organisation to meet employee values.

The researcher explain that, employees would be encouraged to perform better when they- take part in decision making, are rewarded through promotions, compensations, and pay increase. These will urge, and drive employee's behaviour towards specific goals and take the company to the next level.

In order to encapsulate the essence of communication, he argued that successful organisations with employee loyalty, commitment and satisfaction have a clear sense of communication and direction that defines the organisational goals and strategic objectives. Communication is the transmission of information such as ideas, facts, feelings and respect etc. from one worker to another or to a group of workers in the organisation. He argues that when there is a gap in communication, workers are left in suspense, not knowing what to do. Treating employees with respect means treating customers with respect because a respected employee is always proud and strong to meet customers and invite new ones.

\section{Empirical findings and discussions}

This chapter presents findings obtained through analysis of responses and presents a detailed discussion of the same while referring back to the literature reviewed earlier in this report.

Table 4 answers the researcher question one (RQ1) on organisational culture. This table shows the degree of the 50 respondents who were working in all the four branches of the Bank in Oxford on the research question; "Do organizations with high adhocracy of culture traits such as motivation, growth opportunity, communication and supervision ensure employee job satisfaction?" The researcher provided four (4) survey questions for RQ1 (Table 4).

Table 4 above shows the degree of response of employees on whether organizations with high adhocracy of culture traits such as motivation, growth opportunity, communication and supervision ensure employee job satisfaction?

Under this table, there were three (3) survey questionnaires that seek to answer the research question: Do organizations with high adhocracy of culture traits such as motivation, growth opportunity, communication and supervision ensure employee job satisfaction? Considering the Table 4 , it could be seen that, out of the 50 employees used for the study, 20 of them representing $40 \%$ of the employees from all the four branches in Oxford strongly agreed that organisation with high adhocracy of motivation such as compensation, job security, fairness in payment and benefits, support with personal and family matters as well as rewarding have a strong effect on employee job satisfaction. $20(40 \%)$ of the population agreed, $3(6 \%)$ disagreed, 5 (10\%) strongly disagreed and 2 of them representing $4 \%$ neither agreed nor disagreed.

Also, the employees were certain that organisations with a clear understanding of its employee growth opportunities are likely to win employee loyalty and job satisfaction. The employees with an average score of $80 \%$ confirmed that organisations with a clear understanding of its employee growth opportunities such as learning, career development and training are likely to win employee loyalty and job satisfaction within the organisation.

More so, the average score of $46 \%$ penetrated from respondents indicated that, employees believed that communication on important matters can help to resolve problems associated with employee job satisfaction. Effective communication is the most basic need of the employees that help them to tackle the problems of the company and also tackling these problems will make them feel part of the company. Lack of communication creates confusion and leads to job dissatisfaction from employees [26].

When employees from all the four branches were asked "whether organisations with supervisory support for its employees are likely to win employees job commitment?", out of 50 employees from all the four branches, 44 of them representing $(88 \%)$ strongly agreed and agreed, 4 (8\%) strongly disagreed and disagreed and 2 employees representing $4 \%$ neither agreed nor disagreed.

The responses from the above clearly indicate that organisations with culture traits of motivation, communication, growth opportunities and supervisory support have positive effect on employee job satisfaction. Table 5 below demonstrates the rate of response from the employees on the impact of organisational culture on job satisfaction. In this table, the researcher wanted to find out "whether their organisational culture has a significant impact on the employee job satisfaction?

The employees gave a negative response when they were asked if the organisation's employee policies were made in a way to improve their relationship with the company. The average score of $66 \%$ showed that the employees strongly disagreed (strongly disagree $\%$ + disagree $\%=66 \%$ ) in the survey question. The response from the employees suggests that the top management are not too concerned if the needs of the employees are met to the fullest. There are no strategies 
Citation: Asiedu E (2015) Supportive Organizational Culture and Employee Job Satisfaction: A Critical Source of Competitive Advantage. A Case Study in a Selected Banking Company in Oxford, a City in the United Kingdom Int J Econ Manag Sci 4: 272. doi:10.4172/21626359.1000272

Page 6 of 8

\begin{tabular}{|c|c|c|c|}
\hline $\begin{array}{l}\text { RQ2. Do organizations with high adhocracy of culture traits such as motivation, growth } \\
\text { opportunity, communication and supervision ensure employee job satisfaction? }\end{array}$ & Four (4) Branches $(\mathrm{N}=50)$ & Frequency & Percentage \\
\hline $\begin{array}{l}\text { Do you think that organisation with high adhocracy of culture trait of motivation such as employee } \\
\text { rewarding, and compensation ensures job satisfaction? }\end{array}$ & $\begin{array}{c}\text { Strongly agree } \\
\text { Agree } \\
\text { Neutral } \\
\text { Disagree } \\
\text { Strongly disagree }\end{array}$ & $\begin{array}{c}20 \\
20 \\
2 \\
3 \\
5\end{array}$ & $\begin{array}{c}40 \\
40 \\
4 \\
6 \\
10\end{array}$ \\
\hline $\begin{array}{l}\text { Do you think that organisations with a clear understanding of its employee growth opportunities are } \\
\text { likely to win employee loyalty? }\end{array}$ & $\begin{array}{c}\text { Strongly agree } \\
\text { Agree } \\
\text { Neutral } \\
\text { Disagree } \\
\text { Strongly disagree }\end{array}$ & $\begin{array}{c}20 \\
20 \\
4 \\
3 \\
3\end{array}$ & $\begin{array}{c}40 \\
40 \\
8 \\
6 \\
6\end{array}$ \\
\hline $\begin{array}{l}\text { Do you think that communications on important issues within organisations contributes to employee } \\
\text { job satisfaction? }\end{array}$ & $\begin{array}{c}\text { Strongly agree } \\
\text { Agree } \\
\text { Neutral } \\
\text { Disagree } \\
\text { Strongly disagree }\end{array}$ & $\begin{array}{c}23 \\
10 \\
5 \\
5 \\
7\end{array}$ & $\begin{array}{l}46 \\
20 \\
10 \\
10 \\
14\end{array}$ \\
\hline $\begin{array}{l}\text { Do you think organisations supervisory support for its employees are likely to win employees job } \\
\text { satisfaction? }\end{array}$ & $\begin{array}{c}\text { Strongly agree } \\
\text { Agree } \\
\text { Neutral } \\
\text { Disagree } \\
\text { Strongly disagree }\end{array}$ & $\begin{array}{c}19 \\
25 \\
2 \\
2 \\
2\end{array}$ & $\begin{array}{c}38 \\
50 \\
4 \\
4 \\
4\end{array}$ \\
\hline
\end{tabular}

Table 4: Organisational culture.

\begin{tabular}{|c|c|c|c|}
\hline $\begin{array}{l}\text { RQ2. Does the organisational culture in your company have a significant } \\
\text { impact on the employee job satisfaction? Survey Questions: }\end{array}$ & Four (4) Branches $(\mathrm{N}=50)$ & $\begin{array}{c}\text { Frequency } \\
\text { (Respondents) }\end{array}$ & $\begin{array}{l}\text { Percentage (\%) } \\
\text { (Respondents) }\end{array}$ \\
\hline \multirow{5}{*}{$\begin{array}{l}\text { Your organisation's employee policies are directed at improving your job } \\
\text { satisfaction? }\end{array}$} & Strongly agree & 5 & 10 \\
\hline & Agree & 5 & 10 \\
\hline & Neutral & 7 & 14 \\
\hline & Disagree & 10 & 20 \\
\hline & Strongly disagree & 23 & 46 \\
\hline \multirow{5}{*}{$\begin{array}{l}\text { Do you think top management make all effort to develop and implement } \\
\text { employee policies such as training, supervisory and growth opportunities to } \\
\text { ensure job satisfaction? }\end{array}$} & Strongly agree & 7 & 14 \\
\hline & Agree & 3 & 6 \\
\hline & Neutral & 5 & 10 \\
\hline & Disagree & 15 & 30 \\
\hline & Strongly disagree & 20 & 40 \\
\hline \multirow{5}{*}{$\begin{array}{l}\text { Do you think that your organisational culture helps to align goals, motivate } \\
\text { employees and improve performance? }\end{array}$} & Strongly agree & 5 & 10 \\
\hline & Agree & 5 & 10 \\
\hline & Neutral & 7 & 14 \\
\hline & Disagree & 10 & 20 \\
\hline & Strongly disagree & 23 & 46 \\
\hline \multirow{5}{*}{$\begin{array}{l}\text { Do you think that organisational culture values and behaviours significantly } \\
\text { affect your job satisfaction? }\end{array}$} & Strongly agree & 25 & 50 \\
\hline & Agree & 15 & 30 \\
\hline & Neutral & 4 & 8 \\
\hline & Disagree & 3 & 6 \\
\hline & Strongly disagree & 3 & 6 \\
\hline \multirow{5}{*}{$\begin{array}{l}\text { Do you think top management make all effort to develop and implement } \\
\text { employee policies to ensure job satisfaction? }\end{array}$} & Strongly agree & 8 & 16 \\
\hline & Agree & 8 & 16 \\
\hline & Neutral & 6 & 12 \\
\hline & Disagree & 13 & 26 \\
\hline & Strongly disagree & 15 & 30 \\
\hline \multirow{5}{*}{$\begin{array}{l}\text { Do you think that employee related policies and strategies are well } \\
\text { communicated to all departments in the organisation? }\end{array}$} & Strongly agree & 7 & 14 \\
\hline & Agree & 3 & 6 \\
\hline & Neutral & 5 & 10 \\
\hline & Disagree & 15 & 30 \\
\hline & Strongly disagree & 20 & 40 \\
\hline
\end{tabular}

Table 5: Demonstrates the rate of response from the employees on the impact of organisational culture on job satisfaction. In this table, the researcher wanted to find out "whether their organisational culture has a significant impact on the employee job satisfaction?"

designed and implemented to improve the functioning of employee satisfaction within the organization. If the policies are not directed to improve relationship with employees then it is futile to serve in the industry. Even the employees felt that the policies should be changed as they feel liable for the poor service they provide to the customers. They are at the receiving end and most of the times have to hear harsh words from the customers [27].

In addition, nearly all the employees strongly disagreed that 
top management show commitment towards their development. The average score of $70 \%$ (strongly disagree $\%+$ disagree $\%=70 \%$ ) penetrated that the employees felt that the top management do not care about their welfare and development. Employees complained of not receiving enough training. They believed that the company is not spending enough money and time on training their staff. This is one of the reasons why employees are dissatisfied with their job at the selected banking company. If this area is not taken care of, then the company might lose valuable employees and competitive edge with time [28].

Moreover, the survey question three (3) on Table 5 indicates that 35 (70\%) of the respondents from all the four Sainsbury stores in Oxford strongly disagreed that the culture of the organisation helps to align goals, motivate employees and improve job performance and loyalty. This shows that the spirit of the workers at the working environment and individual needs were not satisfied. Management should know that high morale makes employees more responsible, turn to support each other (coordination and teamwork) and increase productivity. However, if this area is not well taken care of, the company's productivity for subsequent years will be low because a worker with low morale is always dissatisfied and employee job dissatisfaction leads to low productivity.

Taking critical look at the Table 5 (survey Q4), the data provided revealed that majority of the employees with a frequency of $40(80 \%)$ score rate showed that employee did agree that such values and behaviours have significant effect on job satisfaction. However, the organisation doesn't have such values and behaviours to improve the style of employee job performance and continuous quality awareness. Management should therefore introduce employee norms, values and objectives which are important to understand the organisational culture.

Further, the employees were of the opinion that the top management do not make a very good effort in developing and implementing employee policies. The average percentage scored, $56 \%$ (strongly disagree $\%+$ disagree $\%=56 \%$ ) of the respondents believe top management do not encourage communication between different departments of the organisation. It is therefore essential for top management to ensure that there is communication taking place between all the departments within the organisation.

The entire employees disagree that the employee job satisfaction of the selected banking company is effective. This is mainly because there is nothing the company is doing right to work and monitor for the progress of their employee job satisfaction strategies. Firstly, there is no training provided to the employees of the company and they face it very hard to tackle the problems of the company. Secondly, there are no motivational factors that could motivate the employees to perform better and offer excellent customer service to position the company higher. Lastly, participation between different departments of the organization is not encouraged which results in lack of sharing in employee related information. Participation has to come from all the members of the organization to hold the overall organisation together. The organization does not look too eager to invest in the employee job satisfaction at the moment [29] and that's why it is losing competitive advantage over its competitors.

\section{Results and Conclusion}

The discussion found out that the employees were neither motivated enough to perform better nor were they given adequate training. The top management were also not too eager to implement strategies and policies to ensure employee job satisfaction. There was not much communication taking place between the different department of the organizations and the top management did not do much about it.

Taking all these facts into account, it could be said that the selected banking company in Oxford City, UK are only to blame itself for lagging behind due to lack of employee job satisfaction activities. Neither are the employees happy nor are the customers of the company. The amount of complaints received is solely because of the fact that the company is not doing anything vital to eradicate the problem. Each year, there is an increase in the number of complaints and more and more employees are switching to different companies as a result of the way and manners the top management do their things in the company. If the company does not take proper measures on their organisational culture to solve the problems discussed, then there would be more employees switching to other companies in the near future.

\section{Recommendations for Further Studies}

This study gathered information about a selected banking company in oxford, UK with the help of statistical analysis. The study was evaluated on the assumptions based on the information gathered from the respondents with the help of statistical approach. This research could further be improved if more statistical analysis is applied. This will help to penetrate the results of organizational culture and its impact on employee job satisfaction at the selected banking company.

Prospective researchers can also research into causes of employee dissatisfaction and its impact on the organisation. Another area of interest should also dwell on the impacts of poor organisational culture on customer relationship management.

\section{Suggested Strategic Recommendations}

The following suggested recommendations should allow the selected bank to take advantage of restructuring their organisational culture to empower employees through motivation, growth of opportunities, communication on important matters and supervisory support.

$>$ The management of the bank should motivate their employees through fair rewarding, compensations, job security, fairness in appraisal and promotions, fairness in payment and benefits to reduce the fear and anxiety from employees. Motivation is a double-edge sword that averts fear and anxiety from employees and urges, drives, inspires and directs their behaviours towards specific goals. It helps to induce or coax employees to achieve a certain level of performance. The management should know that the organisational goals of the company can only be achieved by the efforts of the employees. Therefore they should create the aforementioned conditions to encourage the employees to get the best out of them to achieve its goals.

$>$ The management of the bank should implement learning programmes like training, education and career development to enhance employee skills on their jobs. This will help the employees to develop a positive attitude towards their jobs. The management should know that any organisation that provides growth of opportunities on suitable basis always enjoy satisfactory job done from employees on their jobs.

$>$ The management of the bank should make communication important between all departments and should be regular to find out how their employees are doing. Effective communication such as exchange of ideas, facts, emotions, respect builds teamwork and good relationship with co-workers. Procedures should be 
Citation: Asiedu E (2015) Supportive Organizational Culture and Employee Job Satisfaction: A Critical Source of Competitive Advantage. A Case Study in a Selected Banking Company in Oxford, a City in the United Kingdom Int J Econ Manag Sci 4: 272. doi:10.4172/21626359.1000272

Page 8 of 8

put in place to ensure that there is flow of information through communication from all the departments. Communication on important matters with employees will affect their performance, behaviour and attitudes towards their job. The management should note that the work climate on how the worker fits into the group, both formal and informal, can make them feel confident and accepted.

The management of the bank should make supervisory support important within the organisation. Effective supervisory support such as support with personal and family matters, fairness in personal procedures can have a considerable impact on employees' job satisfaction. If management are fair, firm and show concern for employees, it improves their trust and confidence in them, thereby improving performance on the job. The management should note that poor supervisory support is likely to frustrate employees and lower their performance on the job.

\section{References}

1. Taber TD, Seashore SE (1975) Job satisfaction and Correlations: American Behavior and Scientist 18: 346-356.

2. Hoppock R, Spiegler S (1938) Job Satisfaction. Occupations: The Vocational Guidance Journal 16: 636-643.

3. Jiang JJ, Klein G (2000) Supervising Support and Career Anchor Impact on Career Satisfactionof the Entry Level Information System. Journal Management of Information System 16: 219-240.

4. Mckinnon LJ (2003) Organisational Culture: Association with commitment, job satisfaction, propensity to remain and information sharing in Taiwan. Intenational Journal of Business Studies 11: 25-44.

5. Rad A (2006) A Study on the Relationship between Managers and Leadership and Employees Job Satisfaction. Leadership in Health Services 19: 11-28.

6. Chang S, Lee MS (2007) A Study on the Relationship among Leadership and Organisational Culture, Operations of Learning Organisation and Employee Job Satisfaction. Learning Organisation 14: 155-185.

7. Arnold T, Spell SC (2006) The relationship between Justice and Benefits Satisfaction. Journal of Business and Psychology 20: 599-620.

8. Riley J (2014) Organisational Culture: Strong and Weak. Buisness.

9. Kathryn $A B(2002)$ OrganisationalCulture.

10. Perrow C (2014) Complex Organisations: A Critical Essay. Echo Point Books and Media, USA.

11. March JG, Simon HA (1958) Organisations. John Wiley and Sons, New York.

12. Schneider B, Reicher AE (1983) On the Etology of Climates. Personnel Psychology 36: 19-39.

13. Merton RK (1949) Social Theory and Social Structure. Glencoe, Free Press, USA
14. Schein EH (2010) Organisational Culture and Leadership. Jossey-Bass, San Francisco, USA.

15. Gutknect MD, Miller JR (1990) The Organisational and Human Source Book, Press of America, New York.

16. Kerego K, Muthupha DM (1997) Job Satisfaction as perceived by Agricultural Extension in Swaziland. South African Journal of Agriculture Extension 23: 19-24.

17. Lock EA (1976) Natures and Causes of Job Satisfaction in MD Dunnette (Ed.) Handbook of Industrial and Organisational Psychology, Chicago, USA.

18. Reilly CA, Robert KH (1979) Some Correlations of Communication roles in Organisations. Academy of Management Journal 22: 42-57.

19. Kram KE (1985) Mentoring at Work Development Relationships in Organisational Life. Glenview, Scott Foreman and Company, USA.

20. Sampene M (2002) Job Satisfaction in relation to organisation Culture. SA Journals of Industrial Psychology 28: 23-30.

21. Huang YS, Chi TC (2004) Internal Marketing, Organisational-Class Tourist Hotels in Tawain. Journal of Management and Systems 11: 485-507.

22. Mansoor M, Tayib M (2010) An Empirical Examination of Organisational Culture, job stress, job satisfaction with the indirect tax administration in Malaysia International Journal of Business and Social Sciences 1: 81-95.

23. Yousaf DA (1998) Satisfaction with Security as a Predictor of Organisational Commitment and Job performance in Multicultural Environment. International Journal of Manpower 19: 184-194.

24. Clugston M (2000) Does Cultural Socialization Predict Multiple Bases and Foc of Commitment? Journal of Management 28: 5-30.

25. Bhattacharya DK (2006) Research Methodology. 2nd ed. New Dehli: Excel Books.

26. Finnegan D, Willcocks LP (2007) Implementing CRM: From Technology to Knowledge. Chichester: John Wiley and Sons, USA.

27. Varajao J (2012) Customer Relationship Management and the Social and Semantic Web. Hershey: Idea Group Inc.

28. Coleman M, Briggs ARJ (200) Research Methods in Educational Leadership and Management. London: SAGE Publications.

29. Keyton JN (2011) Communication and Organizational Culture: A Key to Understanding Work. London: SAGE Publications. 